\title{
FRIENDSHIP WITH GOD AS AN ULTIMATE IDEAL IN THE WRITINGS OF PHILO OF ALEXANDRIA ${ }^{1}$
}

M A R K ÉTA DU D Z I K OVÁ

\section{ABSTRACT}

Philo of Alexandria wrote about what it meant to be a 'friend of God' in relation to key biblical figures. This article explores to what extent Philo's understanding of the human relationship to God was inspired by the Greek concept of friendship based on the equal reciprocation of similar goods. It also addresses the complexity of Philo's view of such a relationship and the notion that to become a friend of God is to realise an ideal state of being. I will also illustrate Philo's influence on early Christian authors Clement of Alexandria and Gregory of Nyssa.

Keywords:

Friendship; Philo of Alexandria; Friend of God; Reciprocity; Moses; Abraham; Equality; Gregory of Nyssa

DOI: $10.14712 / 23363398.2020 .55$

$\mathrm{F}_{\mathrm{r}}$ riendship with God is one of the most important themes not only in the writings of Philo of Alexandria, but also in the early Christian literature. But can it be claimed as a novel idea in the context of the Greek philosophical tradition? ${ }^{2}$ The main objection to the

1 This study was funded by the Czech Science Foundation (GA ČR 19-18046S: 'The relationship between the uncreated God and created beings according to Gregory of Nyssa as a follow-up to the Alexandrian biblical exegesis') and the Charles University Research Centre Programme (No. 204053).

2 For ancient concepts of friendship, cf. Ludovic Dugas, L'amitié antique (Paris: F. Alcan, $1914^{2}$ ); Kurt Treu, 'Freundschaft,' in Reallexikon für Antike und Christentum, vol. 8, eds. Theodor Klauser et al. (Stuttgart: Anton Hiersemann, 1972), col. 418-434; JeanClaude Fraisse, Philia. La notion d'amitié dans la philosophie antique. Essai sur un problème perdu et retrouvé (Paris: Librairie philosophique J. Vrin, 1974); Alfons Fürst, 
possibility of friendship with God is the connection between friendship and equality. The idea that God brings together those who are similar or equal is to be found in the Odyssey XVII,218, which is quoted by both Plato and Aristotle within their discourses on friendship. ${ }^{3}$ In the saying $\varphi \imath \lambda i ́ \alpha v$ i $\sigma o ́ \tau\rceil \tau \alpha$, regarded as Pythagorean, friendship is even identified with equality. ${ }^{4}$ The most elaborated theory of friendship as a peer-based relationship is to be found in Aristotle. To show the problematic character of calling a person 'a friend of God', I will briefly introduce Aristotle's objections against the possibility of friendship between a person and a god.

Aristotle's concept of friendship is discussed above all in the eighth and ninth books of the Nicomachean Ethics and in the seventh book of the Eudemian Ethics. ${ }^{5}$ For Aristotle, friendship is so closely connected with equality that it renders impossible the idea that two persons who differ in important qualities such as virtue, power or wealth could ever become friends. Aristotle uses the term 'friendship is equality' ( $\varphi \imath \lambda$ ó $\tau \varsigma \varsigma$ i $\sigma o ́ \tau \eta \varsigma)^{6}$ to explain the nature of one type of relationship in which friends give each other what is equal in return. ${ }^{7}$ Such typical friendships 'depend on an equality, since each gets the same things from the other, and they wish the same things to each other' ${ }^{8}$ But Aristotle also considers less typical friendships, those based on superiority. In these cases, equality is achieved through friendly affection that corresponds

Streit unter Freunden: Ideal und Realität in der Freundschaftslehre der Antike (Stuttgart - Leipzig: Teubner, 1996); David Konstan, Friendship in the Classical World (Cambridge: Cambridge University Press, 1997); John T. Fitzgerald (ed.), Greco-Roman Perspectives on Friendship (Atlanta: Scholars Press, 1997); Suzanne Stern-Gillet and Gary M. Gurtler (eds.): Ancient and Medieval Concepts of Friendship (New York: State University of New York Press, 2014).

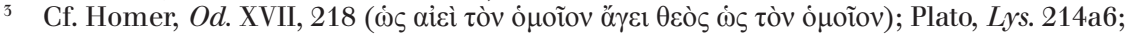
Aristotle, Eth. Eud. VII,1,1235a7; for a similar idea in the Bible, cf. Sir 13,15-16. For a more detailed discussion of this issue, cf. Fürst, Streit unter Freunden, 236-242.

4 The saying ' $\varphi \imath \lambda i ́ \alpha v$ iøó $\eta \eta \alpha$ ' is attributed by Diogenes Laertius, Vitae, VIII,10, to Pythagorean philosopher Timaeus; cf. also Vitae, VIII,33; Plato, Leg. VI, 757a5-6.

5 For Aristotle's theory of friendship, cf. Fraisse, Philia, 89-286; Kelly Rogers, 'Aristotle on Loving Another for His Own Sake,' Phronêsis 39, no. 3 (1994): 291-302; Frederic M. Schroeder, 'Friendship in Aristotle and Some Peripatetic Philosophers,' in Greco-Roman Perspectives on Friendship, 35-57; Gary M. Gurtler, 'Aristotle on Friendship: Insight from the Four Causes,' in Ancient and Medieval Concepts of Friendship, 35-50; Suzanne Stern-Gillet, 'Souls Great and Small. Aristotle on Self-knowledge, Friendship, and Civic Engagement,' ibid., 51-83; Michael Pakaluk, Aristotle's Nicomachean Ethics. An Introduction (Cambridge: Cambridge University Press, 2005), 257-285.

6 Aristotle, Eth. Nic. VIII,1157b36; 1159b2-3; 1168b8.

7 Aristotle, Eth. Nic. VIII,1157b35-36.

8 Cf. Aristotle, Eth. Nic. VIII,1158b1-3. 
to worth. ${ }^{9}$ However, if the equality between two persons becomes too imbalanced, the parties can no longer be considered friends. ${ }^{10}$ Adhering to such a model, it would be entirely logical to dismiss the prospect of a mortal person befriending an immortal god. ${ }^{11}$

Considering this presumption of equality, it is perhaps unsurprising that Philo and others debated the admissibility of human friendship with God. In the Hellenistic period, however, friendship was also (though not exclusively) a political concept: ${ }^{12}$ 'friend' was a term used to describe the advisor to a king or ruler. This relationship was based more on the political than the personal: because the 'friend' of a king cannot be equal in terms of power, status or wealth, equality is not strictly presupposed to the extent it is by classical scholars. Unlike the deceiver who flatters, the true friend of a ruler must care more about the king's prosperity than his own, but also must not shy away from offering frank criticism. In this way, the counsellor is afforded the right to speak openly ( $\pi \alpha \rho \rho \eta \sigma i \alpha)$ with his superior. ${ }^{13}$ Accordingly, this relationship approximates a peer-based friendship.

The most comparable parallel to the Philonic concept of friendship with God is provided by Stoicism. ${ }^{14}$ According to the Stoic philosophers, the whole world is understood as the only true city of people and gods, whose citizens are connected by love and friendship..$^{15}$ There was talk

9 Cf. Aristotle, Eth. Nic. VIII,1158b23-1159b4; cf. also Michael Pakaluk, 'Commentary,' in Aristotle's Nicomachean Ethics, 91-96.

10 Cf. Aristotle, Eth. Nic. VIII,1158b33-1159a5.

11 Cf. Aristotle, Eth. Nic. 1159a5-12; cf. also Michael Pakaluk, Aristotle Nicomachean Ethics: Books VIII and IX (Oxford: Oxford University Press, 1998), 91-99; Jens Timmermann, 'Why We Cannot Want Our Friends to be Gods: Comments on NE 1159a5-12,' Phronêsis 40, no. 2 (1995): 209-215.

12 Cf. Peter Astbury Brunt, “Amicitia” in the Late Roman Republic,' Proceedings of the Cambridge Philological Society, no. 11 (191), (1965): 1-20, doi: 10.1017/ S0068673500003163.

13 For context to the Hellenistic debates on $\pi \alpha \rho \rho \eta \sigma i \alpha$, cf. Plutarch, Quomodo adul. Cf. also Konstan, Friendship in the Classical World, 93-121; the same, 'Friendship, Frankness and Flattery,' in Friendship, Flattery, and Frankness of Speech: Studies on Friendship in the New Testament World, ed. John T. Fitzgerald (Leiden: Brill, 1996), 7-19; Jiří Pavlík, 'Funkce výrazu $\pi \alpha \rho \rho \eta \sigma i ́ \alpha$ a charakteristické př́iklady jeho uplatnění v homiliích Jana Chrýsostoma na Skutky apoštolů,' AUC Theologica 6, no. 2 (2016): 91-117. doi: 10.14712/23363398.2016.16.

14 For the Stoic concept of friendship, cf. Adolf Bonhöffer, Die Ethik des Stoikers Epictet (Stuttgart: Ferdinand Enke, 1894), 106-109; Fraisse, Philia, 333-419; Bernard Collette-Dučić, 'Making Friends. The Stoic Conception of Love and Its Platonic Background,' in Ancient and Medieval Concepts of Friendship, 87-115.

15 Cf. Clement of Alexandria, Strom. IV,26,172,2 (= SVF III,327). Cf. also Malcolm Schofield, The Stoic Idea of the City (Chicago - London: The University of Chicago Press, 
of friendship between mortals and gods in Stoicism, but at the same time friendship only takes place among sages: according to Zeno, the founder of Stoic Philosophy, only the sage is citizen, friend, kin and free. ${ }^{16}$ In calling the sages 'friends of gods' ${ }^{17}$ the Stoics say more about wise persons than about the nature of friendship: Likened to the mythical phoenix, ${ }^{18}$ the wise person is given exclusive status and acknowledged to be closest in equality to the divine. ${ }^{19}$ As I will demonstrate, ${ }^{20}$ Philo uses the term 'friend of God' alongside other unique characteristics of the Stoic sage in his portrayal of biblical figures.

The assumption that there exists a continuity between the Greek and Judeo-Christian concepts of friendship has been questioned by David Konstan. ${ }^{21}$ In his article 'Problems in the History of Christian Friendship', Konstan provides an alternative view to Erik Peterson's study 'Der Gottesfreund: Beiträge zur Geschichte eines religiösen Terminus', published in 1923 yet 'still cited as the authoritative essay on the topic'. ${ }^{22}$ In an effort to dispel the prevailing belief that the term 'friend of God' (Gottesfreund) is somehow primarily connected with 14th-century mysticism, Peterson offers an almost entirely unknown history of the term, starting with Xenophon and Plato in antiquity and ending in the Early Middle Ages. ${ }^{23}$ Despite acknowledging Aristotle's objections to the possibility of a person becoming a friend of God, ${ }^{24}$ Peterson's overview, on balance, argues for the absence of any discontinuity between

$\left.1999^{2}\right)$; René Brouwer, The Stoic Sage. The Early Stoics on Wisdom, Sagehood and Socrates (New York: Cambridge University Press, 2014), 90, note 128.

16 losophy after Philo, cf. Epictetus, Diss. 2,22; cf. also Collette-Dučić, 'Making Friends,' 87-88.

17 Cf. Diogenes Laertius, Vitae, VII,124 (= SVF III,631); Lucius Annaeus Seneca, Ep. 81,12 (= SVF III,633); Clement of Alexandria, Strom. I,26,168,4 (= SVF III,332); Margaret R. Graver, Stoicism and Emotion (Chicago - London: University of Chicago Press, 2007), 173-185. 
the ancient Greek concept of friendship with God and that found in Judeo-Christian literature.

In his critical response to Peterson's study, Konstan focuses on different possible meanings of pí $\lambda$ o, the Greek word for friend, along with other words derived from the same root. He stresses the importance of making a distinction between the use of the word píno $\varsigma$ as a noun and as an adjective. Konstan shows how, particularly in connection with an adverbial modifier, the use of the dative and not of the genitive with the

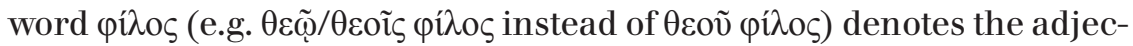
tive, meaning 'dear' or 'friendly' rather than 'friend'.$^{25}$ In a book on the

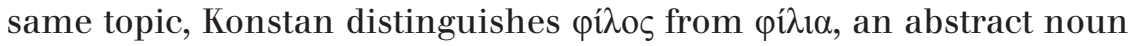
used to describe a set of relationships not exclusively limited to friendship. ${ }^{26}$ Based on the above distinction, Konstan shows that most of the classical instances of the term 'friend of God' quoted by Peterson in fact refer to persons who are either 'dear' to the gods or regard the gods as 'dear' to themselves. According to Konstan, the classical Greek concept of friendship presupposes relative equality between two individuals, thus making the notion of a person becoming a friend of God inconceivable. ${ }^{27}$ For Konstan, moreover, the Christian view of friendship with God derives wholly from the Bible, 'ow[ing] little or nothing to classical views concerning friendship'. Within Christian thought, then, friendship with God does not 'imply equality or anything approaching equality'.28

Taking the work of Philo of Alexandria and the early Christian authors as my cue, I will question the validity of the assertion that the connection between friendship and equality is entirely absent from the Judeo-Christian concept of friendship with God.

\section{God and people}

Precisely whom was Philo of Alexandria referring to when speaking of 'a friend of God' ( $\varphi$ í $\left.\lambda \circ \theta_{\varepsilon} \theta \varepsilon \tilde{)}\right)$ ? Did he deem it a common appellation

\footnotetext{
Cf. Konstan, 'Problems in the History of Christian Friendship,' 92-93.

26 Cf. Konstan, Friendship in the Classical World, 9. Cf. also the same, 'Greek Friendship,' The American Journal of Philology, 117, no. 1 (1996): 71-94. For the semantic field of the verb $\varphi \imath \lambda \varepsilon i v$, cf. Veronika Černušková, 'Tři stupně lásky v řeckém jazyce? Výrazy „milovat“ a „láska“v klasické řecké literatuře a u církevních otců,' Studia Theologica, 16, no. 1 (2014): 17-45. doi: 10.5507/sth.2014.002.

27 Cf. Konstan, 'Problems in the History of Christian Friendship,' 91-95.

28 Cf. Konstan, 'Problems in the History of Christian Friendship,' 96.
} 
for every servant of God, or did he consider it a unique title? In his article on Philo's concept of friendship, Gregory Sterling argues strongly in favour of the former, teasing out similarities between the Stoic theory of friendship and Philo's. ${ }^{29}$ Of importance here is the connection between friendship with God and the term pí $\lambda 1 \alpha$, which refers, in an ideal sense, to all people. According to Philo, the bonds of $\varphi$ í $\lambda \iota \alpha$ should extend to all Israelites, even to proselytes. ${ }^{30}$ Sterling argues that the basis of such a tie is friendship with God, citing figures whom Philo deems God's friends, especially Moses, Abraham and Jacob. ${ }^{31}$ Sterling concludes that, for Philo, 'friendship meant the enlargement of Judaism to all who shared the same Friend. ${ }^{932}$

If a mutual relationship among all people is contingent on all being friends of God, then to be a friend of God is (or should be) almost as common as being a friend of a human being. But did Philo really believe every Jew and proselyte to be a 'friend of God'? Heeding Konstan's warning against conflating all Greek words with the root $\varphi 1 \lambda$-, I will examine Philo's references to friends of God and the nature of that friendship with Him.

In his statements on the general bond between Israelites and proselytes, Philo omits discussing friends of God per se, but rather speaks of 'friendship' ( $\varphi$ í $\lambda \iota \alpha)$ among people. Although it is true that the basis of this friendship is religious, as a term it more precisely connotes the idea that all people worship and believe in the one God as opposed to the idea that they are each His friend..$^{33}$ One should also note that the honour and

29 Cf. Gregory E. Sterling, 'The Bond of Humanity: Friendship in Philo of Alexandria,' in Greco-Roman Perspectives on Friendship, 203-223. According to Sterling, Philo is 'one of the most important extant witnesses to the Stoic view of friendship' ('The Bond of Humanity,' 205).

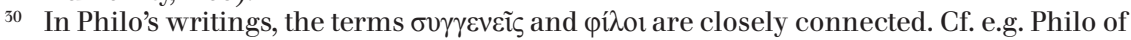
Alexandria, De vit. Moys. I,39; 303; 307; 322; cf. also Sterling, 'The Bond of Humanity,' 217, which gives more references.

31 Cf. Sterling, 'The Bond of Humanity,' 217-218.

32 Sterling, 'The Bond of Humanity,' 222.

33 Cf. Philo of Alexandria, De vit. Moys. II,171: 'between the good there is no kinship and

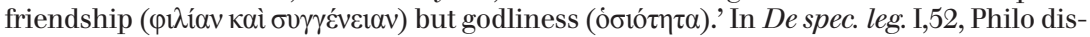
cusses friendship with proselytes, stating that 'the chain which binds indissolubly the

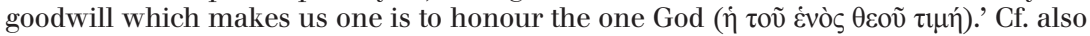

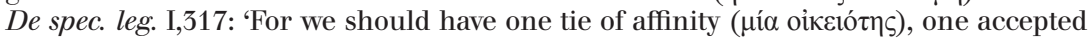

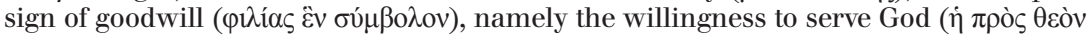

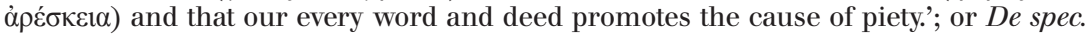

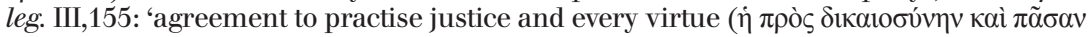

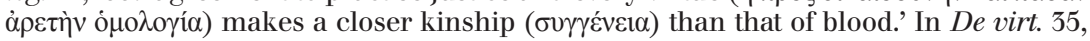

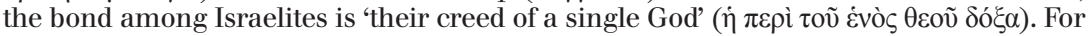


respect paid to the Only Existent is a distinguishing mark of the Israelites $^{34}$ as much as it is of each proselyte who joins their ranks.

Philo addresses the theme of friendship with God in terms of the common bond between Israelites and proselytes in the sub-treatise $O n$

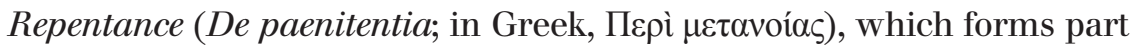
of the treatise De virtutibus. ${ }^{35}$ According to Philo, proselytes 'should be considered our closest friends and relations, having displayed a character

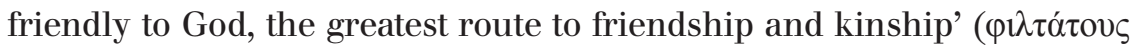

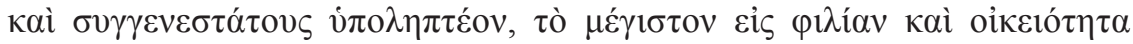

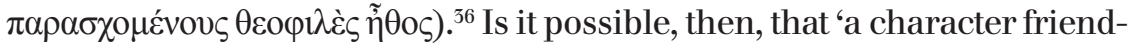
ly to God' $(\theta \varepsilon \operatorname{co} \iota \lambda \dot{\varepsilon} \varsigma \tilde{\eta} \theta 0 \varsigma)$ could infer a kind of friendship with God? Clearly, the words with the root $\varphi 1 \lambda$ - are variations. However, in Philo's writings,

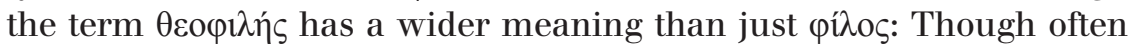
attributed to Moses, ${ }^{37}$ sometimes in the superlative, ${ }^{38}$ it is also used for inanimate objects. ${ }^{39}$ At the beginning of his description of Moses as a high priest in De vit. Moys. II, 67, Philo uses the couple 'God-lover and God-be-

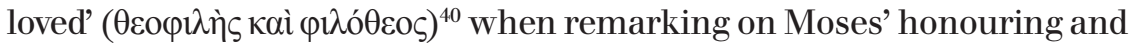
worship of God (and being honoured by Him): Even here, the adjective $\theta \varepsilon \circ \varphi \imath \lambda \eta ́ s$ is more connected to honour and worship paid to God than to friendship with Him, a theme discussed elsewhere in the same treatise. ${ }^{41}$ Therefore, it is probable that in De virt. 179 Philo intended to underscore that the common bond between Israelites and proselytes was their worship of the same God. The use of the phrase $\theta \operatorname{\varepsilon o\varphi } \iota \lambda \grave{\varepsilon} \varsigma \tilde{\eta} \theta 0 \varsigma$ in this context appears to be an allusion to Plato's Respublica. ${ }^{42}$

a new kinship based on virtues, cf. Philo of Alexandria, De spec. leg. II,73; cf. also Walter T. Wilson, 'Introduction,' in Philo of Alexandria, On Virtues, Introduction, Translation and Commentary Walter T. Wilson, Philo of Alexandria Commentary Series, 3 (Leiden Boston: Brill, 2010), 4-5.

Cf. Philo of Alexandria, De virt. 34-35; 64-65. Philo's take on the etymology of the name 'Israel' is: the one who sees God, cf. e.g. De congr. erud. grat. 51. Cf. Philo of Alexandria, De virt.
cf. Wilson, 'Introduction,' 10-23.

36 Philo of Alexandria, De virt. 179; English translation by Wilson (Philo of Alexandria, On Virtues, 79).

37 Cf. Philo of Alexandria, De sacr. Abel. et Caini, 77; De cher. 49.

38 Cf. Philo of Alexandria, De migr. Abr. 67.

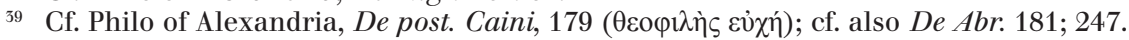

40 Francis Henry Colson, $L C L$ 289, translates: [Moses] 'came to love God and be loved by Him'. Cf. also Philo of Alexandria, De Abr. 50, where it is used about Abraham, Isaak and Jacob.

41 Cf. Philo of Alexandria, De vit. Moys. I,155-158.

42 Cf. Plato, Resp. 501c; 612e. Cf. Walter T. Wilson, 'Commentary,' in Philo of Alexandria, On Virtues, 368. 
For Philo, then, a person's first fundamental attitude towards God is worship, a characteristic quality of the Israelites and the basis for their mutual $\varphi i^{\prime} \lambda 1 \alpha$. In addition, the common bond of $\varphi$ í $\lambda 1 \alpha$ is also available to anyone who forsakes polytheism for worship of the Only Existent One.

In De paenitentia, Philo explains that the move from polytheism to the right faith is the first decisive step, giving an example of the ideal proselyte who reaches a state of high perfection. ${ }^{43}$ To truly worship God and be blessed in all the virtues, the proselyte must harmonise purpose to speech and action to intention, ${ }^{44}$ while leading a life that is 'laudable and perfect'.$^{45}$ Only then can the proselyte, being 'at the same time

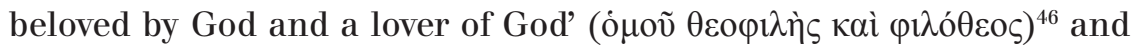

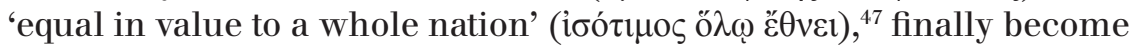
'a sage' (бофó $))^{48}$

For Philo, then, to become perfect, to establish an impeccable relationship with God is something even a proselyte can achieve. However, as we shall learn in the next chapter, this is no easy task; for not everyone who worships God does so to such an exalted level.

\section{Worship of God for His sake alone}

Of those who worship the One God, some are more perfect, dearer to Him. Using the example of God's visit to Abraham by the Oak of Mamre (Gen 18:1-15), in his treatise De Abrahamo Philo explains the differences between one whose relationship with God equates to true 'friendship' ( $\left.\varphi i^{\prime} \lambda 1 \alpha\right)$ and one whose worship is less than perfect. ${ }^{49}$ On the point of the biblical versions of this passage, however, especially the Septuagint translation to which Philo refers, it should be noted that it is not entirely clear whether Abraham is visited by a total of three persons or by the Lord alone. ${ }^{50}$

43 Cf. Wilson, 'Commentary,' 363-364.

44 Cf. Deut 30:14.

45 Cf. Philo of Alexandria, De virt. 184.

46 Philo of Alexandria, De virt. 184. English translation by Wilson (Philo of Alexandria, On Virtues, 80). Philo quotes Deut 26:17-18 as a testimony.

${ }_{47}$ Philo of Alexandria, De virt. 185.

48 Philo of Alexandria, De virt. 186.

49 Cf. Philo of Alexandria, De Abr. 119-130.

50 Cf. (in the Septuagint, to which Philo refers) the difference between 'God' ( $\theta \varepsilon \delta$ s $)$ in Gen 18:1, 'three men' ( $\tau \rho \varepsilon \tilde{\imath} \varsigma$ ö $\delta \delta \rho \varepsilon \varsigma$ ) in Gen 18:2 and Abraham's salutation 'Lord' (Kúpie) in Gen 18:3. Cf. also the variation in pronouns in the singular and plural in the subsequent verses. Cf. Philo of Alexandria, De Abr. 132. 
Philo interprets the passage as reinforcing his view that there exists a distinction between the Existent One and the two 'potencies'

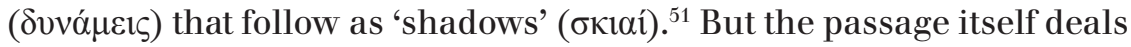
with three people, according to which Philo proposes three ways a person might move toward God (i.e., toward His potencies and toward God Himself) or, more precisely, three ways a person might be motivated toward worshipping God.

Deserving of most admiration are those who worship God for His sake alone, followed by those who worship in the hope of a reward and, finally, those who do so for fear of being punished. Similarly, God can also be viewed (Philo uses the word 'vision', $\varphi \alpha v \tau \alpha \sigma i \alpha)$ in three ways: as a true being, a creative potency or a kingly potency. ${ }^{52}$

But while these differences in motivation are clearly hierarchical, Philo is keen to give the two less disinterested forms of friendship their due. In an echo of the Hellenistic debates on freedom of speech ( $\pi \alpha \rho \rho \eta \sigma i ́ \alpha)$, real friends and flatterers, Philo explains that, instead of distrusting those who offer friendship based on pretence, God in fact embraces all who honour Him regardless of motivation..$^{53}$ Nonetheless, only the person who remains entirely selfless, who worships God for His sake alone, can claim the ultimate reward: ‘friendship' ( $\varphi$ í $\lambda \iota \alpha)$ with God.$^{54}$ Interestingly, nowhere

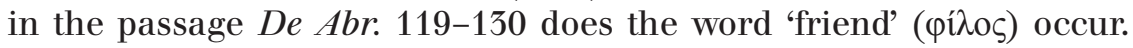

Intriguingly, Aristotle's teachings on friendship are also divided into three categories based on the motivating love for each friendship. ${ }^{55} \mathrm{Just}$ as 'not everything is loved, but only what is lovable, and this is either good, pleasant, or useful, ${ }^{56}$ there are also three kinds of friendship. ${ }^{57}$

51 'Lord and God,' кúpı

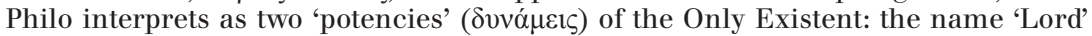

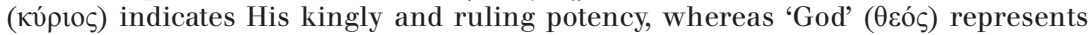
a benefactor and saviour. Cf. e.g. Philo of Alexandria, De conf. linguar. 137; Quaest. Exod. II,62-68; De plant. 86; De sobr. 53-55.

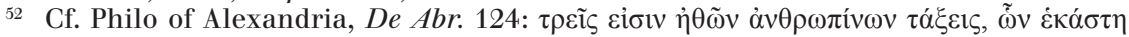

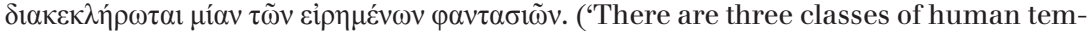
peraments, each of them so constituted that the vision presents itself in one of the three ways abovementioned,' English translation by Colson, LCL 289). Cf. also De Abr. 125; 128; De vit. Moys. I,289.

53 Cf. Philo of Alexandria, De Abr. 126-130.

54 Cf. Philo of Alexandria, De Abr. 128-129.

55 Cf., e.g., Aristotle, Eth. Nic. 1155b-1157b. A similar kind of division was known to Chrysippus; cf. SVF III,98; 723.

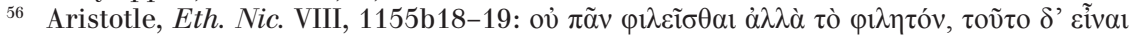

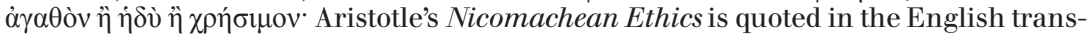
lation by Michael Pakaluk (Aristotle Nicomachean Ethics: Books VIII and IX).

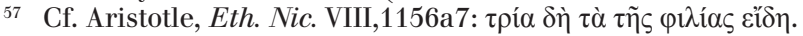




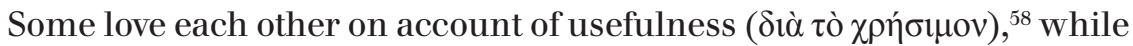
others on account of pleasure ( $\left.\delta \iota^{\prime} \dot{\eta} \delta o v \eta v\right) .{ }^{59}$ The third kind of friendship

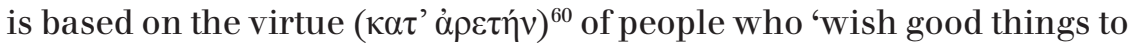
each other as good', or rather, 'wish good things to their friends for their friend's sake'. Only these people are 'friends to the greatest degree' ${ }^{61}$

To what extent, then, is Philo's distinction of these motivations comparable? Well, there are partial similarities. For example, both agree on two fundamental truths: (i) the true value of a relationship is contingent on the reason for forming it, and (ii) the most worthy kind of relationship should be solely on account of ( $\delta$ ió) the other person..$^{62} \mathrm{But}$ for all their similarities, the closest parallel to Philo's categorisation is, in fact, the Stoic teaching that virtue be attained for its own sake and not in hope or fear of something else. ${ }^{63}$

The comparison with the Stoics neatly demonstrates how Philo's distinction embraces two ways of understanding the relationship between God and a human being. For while God guarantees the order of the world, rewarding good behaviour and punishing that which is bad, this does not mean that He dismisses the possibility of friendship. The ultimate friend is not someone who worships God because He is creator and ruler of the world, but someone who does so simply for the fact of it being God Himself. ${ }^{64}$ Only a person

\footnotetext{
Cf. Aristotle, Eth. Nic. VIII,1156a10.

Cf. Aristotle, Eth. Nic. VIII,1156a12.

60 Cf. eg. Aristotle, Eth. Nic. VIII,1158b7; cf. also 1162a25; 1162b7; $1163 \mathrm{a} 21$.

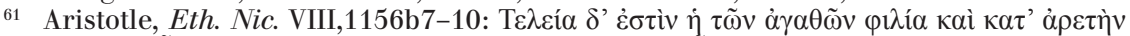

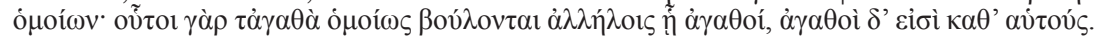

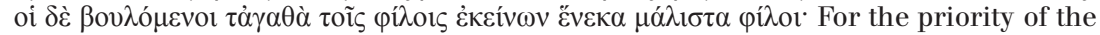
third kind of friendship, cf. Eth. Nic. VIII,1157a30-32 and John M. Cooper, 'Aristotle on the Forms of Friendship,' Review of Metaphysics, 30, no. 4 (1977): 619-648.

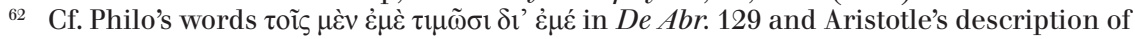

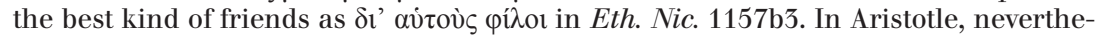
less, it is not the only way how to describe that friends should be loved 'on their own sake' or 'on account of themselves'. On the different phrases used by Aristotle (esp. $\delta$ '

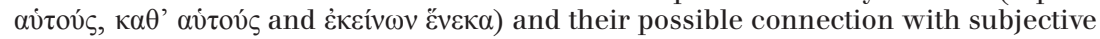
and objective aspects of love, cf. Rogers, 'Aristotle on Loving Another,' esp. note 3 on 292. The Stoics agree with Aristotle on the point that, in a true friendship, a friend is desirable for his own sake ( $\delta \imath^{\prime}$ avióv), cf. Diogenes Laertius, Vitae, VII,124.

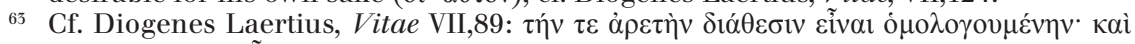

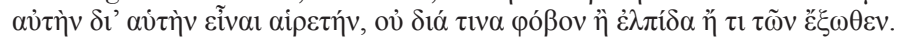

${ }_{64}$ Cf. Aristotle's contention that to give goods to somebody for the recipient's sake alone (an important aspect of friendship) is an attitude possible only among animate beings, cf. Eth. Nic. 1155b27-31.
} 
who establishes such a relationship with God can rightly claim His 'friendship' ( $\varphi$ í $\lambda \iota \alpha) .{ }^{65}$

A similar idea can be found in the works of two Christian authors to be influenced by Philo: Clement of Alexandria and Gregory of Nyssa.

Like Philo, Clement of Alexandria ${ }^{66}$ distinguishes three motivations for a person's actions, whether it be the observance of the Law or the desire to know God: (i) fear of punishment, (ii) yearning after a reward or the hope of promised glory and (iii), the noblest of all, the desire to know God for His sake alone. To these categories, Clement assigns (i) servants, (ii) faithful servants and (iii) friends or sons of God. ${ }^{67}$ For Clement, a person cannot be motivated by another good or being if that person can be said to truly love God. And if it is possible to choose between knowledge of God and eternal salvation, the perfect gnostic will always choose the former. ${ }^{68}$ Clement posits that we are created as desirable simply for being ourselves ${ }^{69}$ and that, similarly, God can only be known and loved for Himself alone.

Yet another variation on the threefold distinction is found at the end of Gregory of Nyssa's Life of Moses (De vita Moysis), a treatise strongly influenced by Philo. ${ }^{70}$ As a way of inspiring the reader to reach a perfect state, Gregory uses the example of Moses befriending God in his final years. ${ }^{71}$ Once again, as with Philo and Clement before him, Gregory considers different motivations that might drive friendship with God. The reason for choosing a virtuous life, Gregory writes, should not be fear of punishment or the hope of a reward, but only the desire to

${ }_{65}$ An example of a group of people whose relationship with God is $\varphi$ í $\lambda 1 \alpha$ are the Therapeutae; cf. Philo of Alexandria, De vit. contempl. 90.

${ }_{66}$ I am grateful to Veronika Černušková for sharing her insights on Clement of Alexandria's theory of friendship.

67 Cf., e.g., Clement of Alexandria, Strom. I,27,173,6; IV,22,135 n.; VII,2,5,6; 3,19,2; 12,72,5.

68 Cf. Clement of Alexandria, Strom. IV,22,135,5. The choice is not possible because knowledge of God and eternal salvation are in fact one and the same thing.

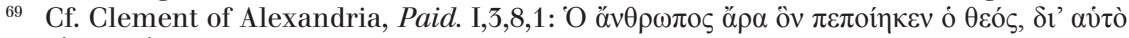

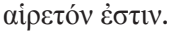

70 Cf. esp. Jean Daniélou, 'Philon et Grégoire de Nysse,' in Philon d'Alexandrie. Lyon 11-15 Septembre 1966, eds. Roger Arnaldez et al. (Paris: Centre National de la Recherche Scientifique, 1967), 333-345; the same, 'Moïse exemple et figure chez Grégoire de Nysse,' in Mö̈se, l'homme de l'alliance (Cahiers sioniens, 8), (Paris: Desclée \& Cie, 1954), 267-282; Albert C. Geljon, Moses as Example: The Philonic Background of Gregory of Nyssa's De vita Moysis (Providence: Universiteit Leiden, 2000); the same, Philonic Exegesis in Gregory of Nyssa's De vita Moysis (Providence: Brown Judaic Studies, 2002).

71 Cf. Helena Panczová, 'Mojžiš - Boží priatel': Priatel'stvo človeka s Bohom ako vrchol duchovného rozvoja (Gregor z Nyssy, Život Mojžiša II,319-321), Studia Theologica, 22, no. 1 (2020): 41-59. doi: 10.5507/sth.2019.020. 
become God's friend. The perfection of life consists in doing good, but only because of that desire and nothing else. ${ }^{72}$

God loves all people in the same way. Adopting a human attitude towards God is what makes all the difference. The only relationship that can be called friendship is a reciprocal one. ${ }^{73}$ The only adequate response man can give to God's love is through the only perfect thing that can be offered: the motivation to love God for His sake alone.

Is it not reasonable to conclude, then, that a human being who loves God for Himself alone becomes in a way equal to Him? Laura Rizzerio, in her article on Clement's ethical theory, interprets this concept of friendship as advocating a kind of equality between God and a person, equality less of ontology and more of action: the answer to God's disinterested beneficence and philanthropy is effected through the recipient's own disinterested love for God and for other people. In this respect, the person becomes equal to God because no reward is sought for the reciprocation of love. ${ }^{74}$

In contrast to Rizzerio, I think there is no direct connection between loving God solely for His sake and equality with Him. For merely stating that human beings are able to love God for His sake alone (as Philo, Clement and Gregory would have it) is not enough to prove their equality with God; all it shows, rather, is a similarity of attitude. The next chapter reveals whether these authors succeeded in finding other ways of framing friendship with God as a personal, reciprocal relationship similar to that formed between peers.

\section{3. 'Friend of God' (Фítos $\theta \varepsilon o \tilde{v})$}

Philo first and foremost interprets the term 'friend of God' in relation to key figures from the Scriptures. Let us look at two of the most

72 Cf. Gregory of Nyssa, De vit. Moys. II,320 (GNO VII/1,144,20-145,4). For the influence of Philo's Abraham treatise on Gregory's treatise on Moses, cf. Markéta Bendová, 'The Influence of Philo's De Abrahamo on Gregory of Nyssa's De Vita Moysis,' AUC Theologica, 8, no. 2 (2018): 91-109. doi: 10.14712/23363398.2018.52.

73 Cf. David Konstan, 'Reciprocity and Friendship,' in Reciprocity in Ancient Greece, eds. Christopher Gill, Norman Postlethwaite and Richard Seaford (Oxford: Oxford University Press, 1998), 279-301.

74 Cf. Laura Rizzerio, 'Leéthique de Clément et les philosophies grecques,' Studia Patristica, 41 (2006): 231-246. Cf. esp. 243: 'malgré les differences, une certaine égalité existe bien entre l'homme et Dieu. Cette égalité ne se situe pas au niveau de la substance, mais de l'action bienveillante.' 
exemplary of these: Moses, the greatest and most perfect of men, ${ }^{75}$ and Abraham. ${ }^{76}$ The primary biblical evidence for Moses being a friend of God is found in Exod 33:11. ${ }^{77}$ The case for Abraham is more complex, however. Although nowhere in the Septuagint translation of the Pentateuch is Abraham called God's pínos, he is referred to as God's 'beloved' in later books. ${ }^{78}$ Elsewhere, both in the New Testament ${ }^{79}$ and in Philo, the term 'friend of God' is attributed to him..$^{80}$

On one occasion in some of the allegorical running commentaries on the book of Genesis, ${ }^{81}$ a citation by Philo differs from an alternate version found in the Septuagint: in De sobrietate, Philo quotes God's speech

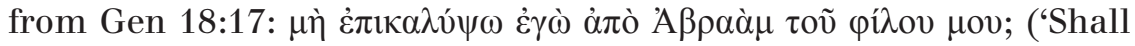
I hide anything from Abraham my friend?'). ${ }^{82}$ Compare this with the Septuagint version, where Abraham is not God's pínos ('friend') but His $\pi \alpha \tilde{\varsigma} \varsigma$ ('child', 'son' or 'servant'). The context of Philo's quotation is an exegesis of Noah's prayer for his son Shem in Gen 9:26: 'Blessed is the

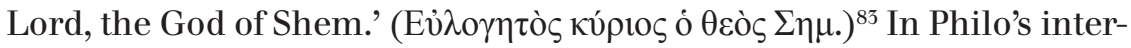
pretation of the prayer, He who is the Lord and God of the entire world turns only His loving and beneficent side towards a good person (represented by Shem). The reference to Abraham supports the idea that the relationship between God and a good person is based not on fear or servitude, but on love and friendship. The change was perhaps made by Philo himself. ${ }^{84}$

75 Cf. Philo of Alexandria, De vit. Moys. I,1.

76 A less important and less frequent example of a friend of God is Jacob; cf. Philo of Alexandria, De somn. I,196.

77 For Moses as a friend of God, cf. Philo of Alexandria, Quis rerum div. her. 21; De somn. I,193-194; De vit. Moys. I,155-157; De sacr. Abel. et Caini, 130; De migr. Abr. 45; De sacr. Abel. et Caini, 130.

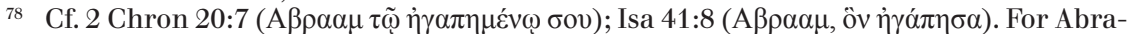
ham as a friend of God, cf. Peterson, 'Der Gottesfreund,' 172-176.

79 Cf. James 2:23.

80 Cf. Philo of Alexandria, De somn. I,193-195; De Abr. 273; De sobr. 55-57.

81 For that part of Philo's exegetical works, cf. James R. Royse, 'The Works of Philo,' in: The Cambridge Companion to Philo, ed. Adam Kamesar (Cambridge - New York: Cambridge University Press, 2010), 32-64, here 38-45.

82 Philo of Alexandria, De sobr. 55 (English translation Francis Henry Colson - George Herbert Whitaker, LCL 247).

83 Philo of Alexandria, De sobr. 51.

84 Cf. Peterson, 'Der Gottesfreund,' 172. Philo quotes the Septuagint wording in Leg. all. III,27. As there is no specific mention of Abraham in the Masoretic Hebrew text (neither 'son' nor 'friend' nor anything else), it is difficult to surmise the contents of the Hebrew original from which the Septuagint was translated. 
The Alexandrian exegete's description of a friend of God is similar to the characteristics that the Stoics typically attributed to the wise person. A person like Abraham who becomes a friend of God, 'pass[ing] beyond

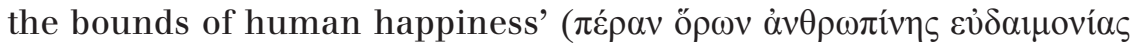

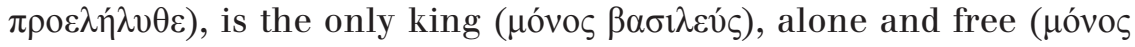
$\dot{\varepsilon} \lambda \varepsilon v \dot{\theta \varepsilon \rho \rho \varsigma) .}{ }^{85}$ Here, a close affinity can also be read between the title 'friend of God' and Philo's version of the Stoic concept of the sage.

Another of Philo's allegorical commentaries reports that 'all the wise

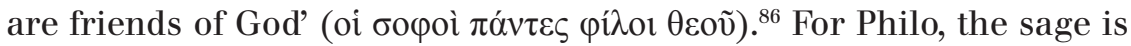
a rare figure indeed, ${ }^{87}$ a view that becomes evident in his treatise $O n$ the Migration of Abraham. Having laid eyes on the (Promised) Land, Moses is denied entry: ${ }^{8}$

You must not think that this was said, as some unconsidering people suppose, to humiliate the all-wise leader; for indeed it is folly to imagine that

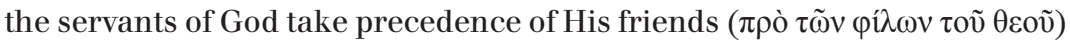
in receiving their portion in the land of virtue. No, what he wishes to bring home to you first of all is that children have one place and full-grown men another, the one named training, the other called wisdom. ${ }^{89}$

There are two groups of people: wise men and children in training. Only members of the first group are called friends of God..$^{90}$

Notably, the term 'friend of God' features prominently in Philo's 'biographical' treatises on Abraham and Moses, De Abrahamo and De vita Moysis. Abraham is called a 'friend of God' at the very end of De Abrahamo, within the context of Philo's summary of his importance

85 Cf. Philo of Alexandria, De sobr. 56-57, which was incorporated into Stoicorum veterum fragmenta, III, Chrysippi fragmenta moralia. Fragmenta successorum Chrysippi, ed. Ioannes ab Arnim (Stuttgart: B. G. Teubner, 1964-1968) as SVFIII,603. Cf. also SVF III,589-602.

86 Philo of Alexandria, Quis heres, 21 (English translation Francis Henry Colson - George Herbert Whitaker, LCL 261).

87 For the rareness of sages, cf. Philo of Alexandria, De sacr. Abel. et Caini, 111; cf. also Carlos Lévy, 'Philo's Ethics,' in: The Cambridge Companion to Philo, 146-171, here 159-161.

88 Cf. Deut 34:4.

89 Philo of Alexandria, De migr. Abr. 45-46 (English translation by Colson - Whitaker, LCL 261.)

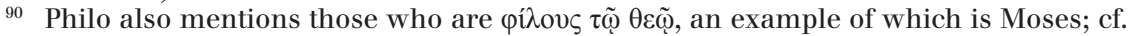
Philo of Alexandria, De ebr. 94. Such people share characteristics of God, cf. Leg. all.

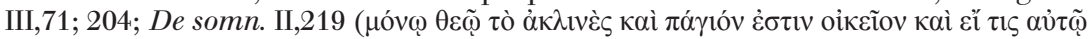
pí̉os) and De somn. II,297; a similar formulation is found in Plato, Tim. 53d6-7. 
of Abraham. ${ }^{91}$ In De vita Moysis, the term is used in connection with the Sinai revelation, which, for Philo, represents the pinnacle of Moses' life. ${ }^{92}$

In the writings of early Christian writers, 'friend of God' is a unique title. In Gregory of Nyssa's De vita Moysis, it is used as a testament to perfection. Gregory presents Moses as an example of perfect virtue, culminating in an account of his friendship with God. Supported by references to biblical events, Gregory contends that Moses was indeed a friend of God and treated as such, evidence that 'the life of Moses did ascend the highest mount of perfection. ${ }^{93}$ So, whatever connotations one gives to the notion of the perfect human being, the ample evidence would suggest that being given the title 'friend of God' is as close as one can get.

I believe the classical ideal of friendship was intrinsic to what Philo and his Christian adherents understood as constituting a 'friend of God'. Compare it with the title 'Son of God' when used about a Christian: this term cannot be understood without realising that, in its primary sense, 'son' denotes someone who shares the nature of his father and who will ultimately become his heir and successor. Similarly, it is always a little bit bold to call a human being 'a friend of God'.

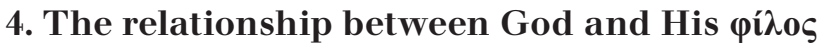

We have explored the various meanings of the title $\varphi$ í $\lambda \circ \varsigma \theta \varepsilon o v$. But let us now focus on the character of the relationship between God and His pí $\lambda$ os. I will consider two aspects Philo addresses: (i) frankness and (ii) the reciprocal sharing of similar goods.

The insights Philo gained from Hellenistic discussions of the classical Greek theory of friendship are evident in his reflections on the frankness of speech $(\pi \alpha \rho \rho \eta \sigma i \alpha)$. Like other Hellenistic philosophers, he criticises flatterers (Кó $\lambda \alpha \kappa \varepsilon \varsigma$ ), connecting true friendship with

91 Cf. Philo of Alexandria, De Abr. 273. I will return to the passage in the next chapter.

92 Cf. Philo of Alexandria, De vit. Moys. I,155-158. For the passage's place within Philo's interpretation of Moses' life, cf. Burton L. Mack, 'Imitatio Mosis: Patterns of Cosmology and Soteriology in the Hellenistic Synagogue,' Studia Philonica, 1 (1972): 27-55, here 27-28. Mack draws attention to parallels between Philo's description of the Sinai theophany in De vit. Moys. I,158 and Philo's account of Moses's death in Quaest. Exod. II,29 and De vit. Moys. II,288-291.

93 Cf. Gregory of Nyssa, De vit. Moys. II,320 (GNO VII/1,144,20-145,4). 
sincerity. ${ }^{94}$ In an observation that echoes the Hellenistic discourse on the friends of kings, ${ }^{95}$ Philo commends Moses and Abraham for their frankness ( $\pi \alpha \rho \rho \eta \sigma i ́ \alpha)$ towards God, a trait he interprets not as a sign of arrogance but of true friendship. ${ }^{96}$ He considers Moses and Abraham true friends of God who should be afforded the opportunity to speak openly with Him. ${ }^{97}$

Let us finally look once more at Philo's account of Abraham's friendship with God. In his remarkable interpretation of the Scripture, Philo considers a kind of reciprocity between God and Abraham whereby goods of the same kind are gifted and returned.

At the very end of De Abrahamo, Philo offers one of several proofs of Abraham's pre-eminence as a friend:

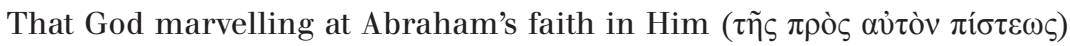
repaid him with faithfulness ( $\pi i \sigma \tau \imath$ ) by confirming with an oath the gifts which He had promised, and here He no longer talked with him as God

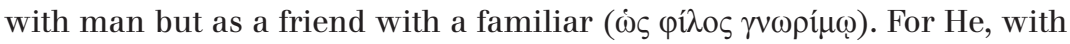
Whom a word is an oath, yet says 'By Myself have I sworn,"98 so that his mind might be established more securely and firmly even than it was before. ${ }^{99}$

There is a play on words in the Greek text: Philo uses $\pi$ í $\sigma ı \varsigma$ to denote two different meanings (Francis Henry Colson translates it as 'faith'

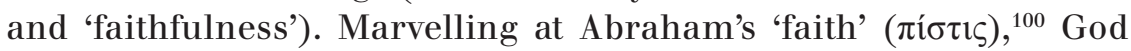
repays him by pledging His 'assurance' $(\pi i \sigma \tau i \varsigma) .{ }^{101}$ In the Septuagint

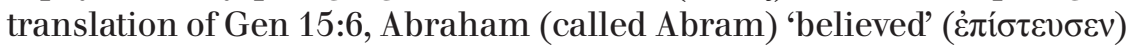

${ }^{94}$ Cf. Philo of Alexandria, De plant. 106; Leg. all. II,10; III,182.

${ }_{95}$ Cf. Konstan, Friendship in the Classical World, 93-121 and above, 11.

${ }^{96}$ Cf. Philo of Alexandria, Quis rerum div. her. 5-7; 21. Cf. also Panczová, 'Mojžiš - Boží priatel', 46-47.

${ }^{97}$ For the meaning of the term $\pi \alpha \rho \rho \eta \sigma i \alpha$ in Christian literature, esp. in Gregory of Nyssa, cf. M. Marunová, ‘Řehořův výklad modlitby Otče náš. Kázání, nebo filosofické pojednání?,' in Řehoř z Nyssy, Otče náš, transl. and comm. M. Marunová (Praha: Oikúmené, 2019), 7-26, here 21-23.

98 Gen 22:16.

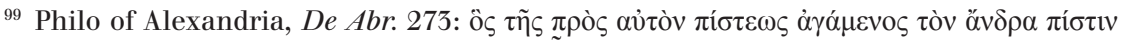

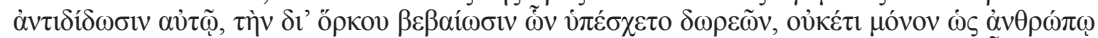

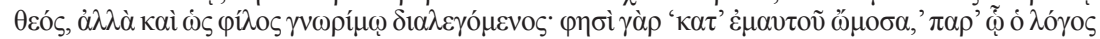

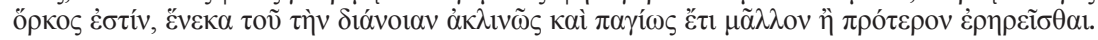
(English translation by Colson, LCL 289.)

100 Cf. Gen 15:6.

${ }^{101}$ For a translation of $\pi i ́ \tau \tau \iota \varsigma$ as 'pledge', cf. Charles D. Yonge, The Works of Philo: Complete und Unabridged (Peabody: Hendrickson, 2002), 434. 
in God. As Philo would have it, the 'assurance' ( $\pi i ́ \sigma \tau \imath \varsigma)$ God gives Abraham underscores God's oath from Gen 22:16. ${ }^{102}$ Here, Philo highlights this mutual exchange and reciprocation of the same kind of goods: God

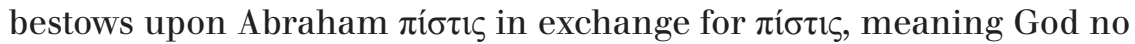
longer speaks with Abraham as the Creator to His creation, but 'as

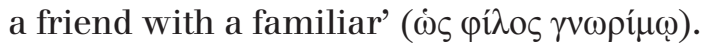

\section{Conclusion}

We have seen how Philo believed a relationship of perfection between God and a person to be more or less akin to the classical idea of friendship. The ultimate example of this is the friendship between God and Moses, whom the Pentateuch calls a 'friend of God'. The same title, Philo argues, can also be applied to Abraham or, indeed, any person who displays sagacious qualities. The basic prerequisite for the formation of such a 'friendship' ( $\varphi$ í $\lambda 1 \alpha$ ) is that, in return for God's love, a person worships God for His sake alone.

Philo's concept of friendship with God was inspired by the defining characteristics of friendship advanced by the Greeks. As such, the more perfect the relationship between a person and God, the closer it mirrors a reciprocal and mutual exchange between equals.

Protestant Theological Faculty, Charles University

Černá 9

11555 Praha 1

Czech Republic

E-mail:dudzikova@etf.cuni.cz

${ }^{102}$ In a similar way, Philo provides commentary on God's oath in Leg. all. III,203-210. 